\title{
Reviews
}

Sikoryak, R. 2020. Constitution Illustrated. New York: Drawn \& Quarterly. 118 pp.

Fans of comics and cartoons will revel in the creative deployment of characters from the funny pages throughout Constitution Illustrated. Artist R. Sikoryak is a contributor to The New Yorker and The New York Times Book Review and is the author of several illustrated books. In his latest work, he has concocted an ingenious ploy to enliven the text of the Constitution. Each page features a different section of the Constitution being recited by cartoon characters. Sikoryak has imitated the style and borrowed the characters of dozens of cartoonists. Readers will find favorites both classic and contemporary, from Bud Counihan's Betty Boop and Chester Gould's Dick Tracy to Alison Bechdel's Dykes to Watch Out For and Harvey Pekar's American Splendor. Aficionados will have fun figuring out the artist being imitated on each page, and a helpful index provides a key to the source of each drawing for those who aren't able to recognize the myriad cartoonists represented.

Each phrase or sentence of the Constitution appears in a speech bubble spoken by a different character. By carefully selecting just the right cartoon characters to portray the words in each section, Sikoryak has created a set of lighthearted tableaux to help readers engage with this weighty text. So, for example, Bugs Bunny stands on a staircase, waving goodbye to a departing Daffy Duck as Daffy recites Amendment XX, which outlines the terms of the president and vice president. Olive Oyl and Popeye, standing aboard a ship, are spitting mad as they take a turn with Article I, Section 9, regarding taxation, while a
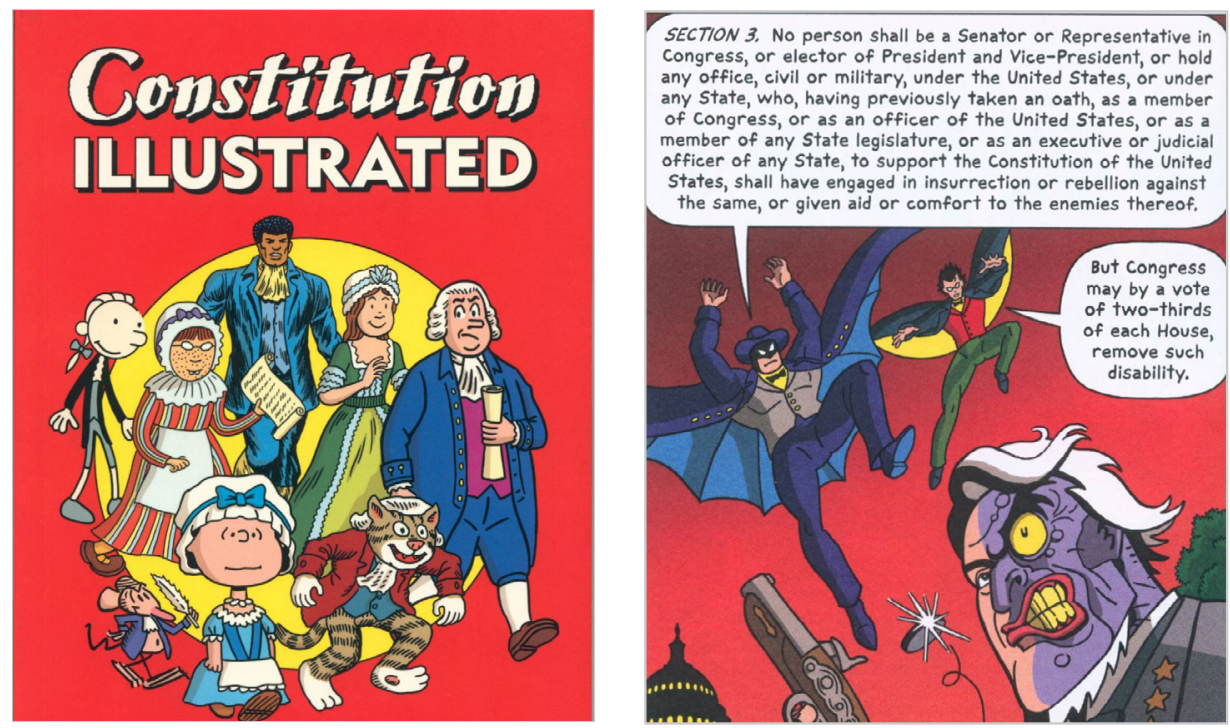

(Left) Artist R. Sikoryak enlivens a founding U.S. document with 4. (Right) Characters from Batman \& Robin Adventures illustrate Amendment XIV, Section 3, (Image Copyright R. Sikoryak, Used with permission from Drawn \& Quarterly)

nonplussed Bluto awaits payment on the dock. To illustrate Article III, Section 3, which concerns treason, Sikoryak placed Boris and Natasha in 18th century garb, awaiting the verdict of bewigged and robed judges Rocky and Bullwinkle.

The book includes articles and amendments that were subsequently modified or repealed, thereby adding to the cartoon character tally. Happily for the reader, this means that Homer Simpson ushers in Prohibition with Amendment XVIII, while characters from Pearls Before Swine celebrate its repeal under Amendment XXI. A notes section at the book's end lists the revisions and a chronology provides the dates of the Constitution and its amendments. A brief bibliography concludes the volume.

Constitution Illustrated is certainly not the first book to take a well-known text and set it to cartoons. R. Crumb, for instance, illustrated The Book of Genesis, which features the complete text of the first book of the Old Testament accompanied by his lurid drawings. Sikoryak previously published Terms and
Conditions, based on the iTunes Terms and Conditions agreement, in which Steve Jobs pops up as a character in various comics and graphic novels. One hopes that we can look forward to more of these types of text/comics mashups by Sikoryak or other artists. Universal Declaration of Human Rights by Roz Chast, anyone?-Gwen Sinclair (gsinclai@ hawaii.edu), Chair of Government Documents and Maps, University of Hawai' $i$ at Mãnoa Library.

\section{RIGHTS! Civil and Human Rights Law Portal}

On September 1, 2020, LLMC, a nonprofit Minnesota-based consortium of law libraries, launched the open-access portal RIGHTS! (http://www.llmc. com/rights/home.aspx). If you are looking for primary materials such as current constitutions, human/civil rights acts, Non-Governmental Organizations' websites, advocacy organizations, and other resources specifically dealing with injustices regarding marginalized parties, this is the place to look. Their 